\title{
EMBEDDEDNESS IN THE MAKING OF FINANCIAL CAPITAL: HOW SOCIAL RELATIONS AND NETWORKS BENEFIT FIRMS SEEKING FINANCING*
}

\author{
Brian Uzzi \\ Northwestern University
}

I investigate how social embeddedness affects an organization's acquisition and cost of financial capital in middle-market banking-a lucrative but understudied financial sector. Using existing theory and original fieldwork, I develop a framework to explain how embeddedness can influence which firms get capital and at what cost. I then statistically examine my claims using national data on small-business lending. At the level of dyadic ties, I find that firms that embed their commercial transactions with their lender in social attachments receive lower interest rates on loans. At the network level, firms are more likely to get loans and to receive lower interest rates on loans if their network of bank ties has a mix of embedded ties and arm's-length ties. These network effects arise because embedded ties motivate network partners to share private resources, while arm's-length ties facilitate access to public information on market prices and loan opportunities so that the benefits of different types of ties are optimized within one network. I conclude with a discussion of how the value produced by a network is at a premium when it creates a bridge that links the public information of markets with the private resources of relationships.

$\mathrm{W}$ hich firms get capital and at what cost? The answer can determine the life chances of firms, the growth of economies, and how markets stratify firms and persons through the rationing and pricing of credit. In financial theory, any firm with a positive economic net present value should obtain credit at a competitive price (Petersen and Rajan 1994). Sociological theory does not necessarily reject this axiom, yet argues that banking transactions are embedded in social relations that uniquely shape credit ac-

\footnotetext{
* Direct all correspondence to Brian Uzzi, Kellogg Graduate School of Management, Northwestern University, Evanston, IL (uzzi@nwu. edu). I thank John Wolken at the Federal Reserve Bank, James Baron, Wayne Baker, Willie Ocasio, Ryon Lancaster, Nan Lin, Mitch Petersen, Holly Raider, Mike Sacks, James G. Gillespie, the bank CEOs and Relationship Managers that contributed their insights to this research, and Northwestern University's Institute for Policy Research and the Kellogg Graduate School of Management's Banking Resource Center for their research support.
}

cess and costs in ways that are inadequately incorporated into financial theory (Baker 1990; Mintz and Schwartz 1985; Mizruchi and Stearns 1994b; Podolny 1993; Uzzi and Gillespie 1999). Bankers and entrepreneurs echo this observation and complain that financial models often do not appreciate the value of bank-client relationships. This suggests that there is a growing demand for sociological theory on finance (Abolafia 1997; Arrow 1998; Haunschild 1994; Mizruchi and Stearns 1994b).

Most sociological research on lending has not focused on the availability and pricing of capital. Rather, classical writings take a philosophical approach to analyzing money economies, and most contemporary work concentrates on how bank-firm ties, coarsely defined as the incidence of a director interlock, affect the politics and level of a firm's borrowing (Baker 1990; Mintz and Schwartz 1985; Mizruchi and Stearns 1994a). These approaches, while productive for certain problems, leave unexplored how the embeddedness of commercial transactions in social 
attachments and networks affects personal and corporate financial dealings (DiMaggio and Louch 1998; Uzzi 1997). Finance research similarly concludes that while bankfirm ties are more critical to lending markets than classical theory suggests, inconsistencies in financial theory also signify a need for more research on how social relationships and networks affect who gets capital and at what cost (Arrow 1998; Petersen and Rajan 1994).

I examine how bank-borrower relationships and networks affect a firm's acquisition and cost of capital using a social embeddedness approach (Granovetter 1985). The social embeddedness approach aims to explain why economic transactions become embedded in social relations that differentially affect the allocation and valuation of resources. Social embeddedness is defined as the degree to which commercial transactions take place through social relations and networks of relations that use exchange protocols associated with social, noncommercial attachments to govern business dealings (Marsden 1981; Uzzi 1997). I argue that embedding commercial transactions in social attachments benefits firms that are seeking financing by promoting distinctive governance mechanisms and the transfer of private information-factors that motivate banks and firms to find integrative solutions to financing problems beyond those possible through market relations, which possess different benefits.

In developing my arguments, I analyze how both social relationships and networks affect lending. At the level of relationships, I draw on research that examines how properties of embedded ties and arm's-length ties promote different kinds of access and governance benefits in market exchanges. At the level of the network, I elaborate on the finding that networks incorporating a mix of embedded ties and market ties provide premium benefits because they enable a firm to synthesize the advantages of partnering via embedded ties with the advantages of brokerage offered by arm's-length ties. I argue that firms are more likely to secure loans and receive lower interest rates if they are tied to their lenders through embedded ties and if their networks of bank ties have a mix of embedded ties and arm's-length ties.
My study aims to enhance sociological theory on finance in several ways. First, I examine the setting of interest rates, the touchstone market mechanism by which value is created, thereby extending sociological research on markets to price formation (Fligstein 1996; Podolny 1993). Second, since financial capital is a substitutable commodity and banks can write nearly complete contracts by holding collateral, this study reveals how social embeddedness operates in the presence of market "efficiency" conditions thought to supplant it (Carruthers 1996). Third, I focus on what bankers dub "the midmarket"- a sector of the economy that has been neglected in research yet deserves closer analysis (Fama 1985). The midmarket is composed of firms with fewer than 500 employees or less than $\$ 500$ million in annual sales and is bountiful in its social and economic effects. The midmarket accounts for more than one-half of the U.S. gross domestic product (GDP), has twice the innovations per employee as large firms, and since 1970 has created two-thirds of the jobs in the United States. In the 1980s, it emerged as a seedbed for entrepreneurship and a source of 16 million of the 20 million new jobs created in that decade.

Before proceeding, it is worth noting the unique qualitative and quantitative materials used in this analysis. Because the effect of embeddedness in financial markets is contested and remains "in need of greater theoretical specification" (Smelser and Swedberg 1994:18), I strengthen my analysis using a triangulation of theory, fieldwork, and statistical analysis (King, Keohane, and Verba 1994). I use original field data on bank-borrower ties to help explicate and illustrate the mechanisms by which embeddedness produces outcomes and actors construct markets. I then use a national random sample of 2,400 companies to test the validity and generalizability of my theory.

\section{THEORY}

The social embeddedness framework is one of several sociological accounts for how social structure affects financial markets (Granovetter 1985; Portes and Sensenbrenner 1993; Romo and Schwartz 1995, Uzzi 1996, 1997). Research has focused on the 
types of social relations and social networks that exist and their economic effects. Following this literature, I treat social embeddedness as a variable and focus on how the quality of relationships and the configuration of ties in a network influence a firm's ability to obtain loans and to lower the cost of borrowing.

Relationships vary between arm's-length and embedded (Baker 1990; Lie 1997; Powell 1990; Uzzi 1996, 1997). Arm'slength ties are characterized by lean and sporadic transactions and "function without any prolonged human or social contact between parties ... [who] need not enter into recurrent or continuing relations as a result of which they would get to know each other well" (Hirschman 1982:1473). Weber (1946) characterized them as lacking social distinction and having an expressive nature that "knows nothing of honor" (p. 192). The main proposition related to arm's-length ties is that they determine the degree to which an actor can access heterogeneous information in a market, even if that information is publicly available through advertising or publicity, because actors use network ties to search for opportunities and investments. For example, Granovetter (1973) found that job-seekers tend to search for and learn about new job openings through acquaintances, even when the jobs were publicly advertised. Davis (1991) found that firms adopted "poison pills" chiefly through interlock ties, despite the takeover defense's public notoriety and marketing by many legal firms. Burt (1992) developed this formulation's most trenchant propositions. He argued that the strategic expansion of networks through the use of arm's-length ties offers the highest possible returns to firms and persons by linking them to diverse pools of market information, which they broker among less informed actors who reside in cloistered networks of relations that hinder their autonomy.

In contrast, there is less theory and empirical justification for expecting that socially embedded ties generate exchange benefits in markets. Recent research on interfirm networks suggests that embedding economic exchanges in social attachments can both create unique value and motivate exchange partners to share the value for their mutual ben- efit. Embedded ties promote these outcomes through the transfer of private resources and self-enforcing governance (Portes and Sensenbrenner 1993; Uzzi 1997). Private resources and private information are distinctive in that they identify where an actor's expertise and dependencies reside. They might include, for example, unpublished capabilities in products, the need to source a particular material, the strategic blueprints for an executive succession, investment plans, failed solutions, the rollout date of a new product, or critical resource dependencies. In essence, private information differs from public market information, such as financial statements or job listings, in that it is not "information for the asking," but information that must be voluntarily transferred in an exchange. In fact, because private knowledge can be misappropriated, it is commonly inaccessible through arm's-length ties and is shared only within a set of trustworthy exchange partners.

The transfer of private knowledge promotes value creation in exchanges by revealing to exchange partners the unique possibilities they possess for matching their competencies and resources. In contrast, public information such as ask-and-bid prices can be a source of value creation, but is less so in competitive markets because it is less restricted and unique than private knowledge and resources. Hence, the solutions prompted by the transfer of private knowledge are valuable not only because they are distinctive, but also because they are hard for competitors without private knowledge to imitate. Consistent with this argument, Eccles and Crane (1988) found that investment bankers were able to customize deals and create innovative risk-reducing financial instruments for their clients when they possessed information and resources beyond what firms made publicly available. Mark Twain Bancshares, a lucrative midmarket bank, gained recognition by using private information to tailor their bank products and loan structures to the distinctive and often confidential capabilities of their customers (Baker 1994).

The embedding of commercial transactions in social attachments promotes the benefits discussed above by enacting expectations of trust and reciprocal obligation that 
actors espouse as the right and proper protocols for governing exchange with persons they come to know well (Blau 1964; DiMaggio and Louch 1998; Portes and Sensenbrenner 1993). ${ }^{1}$ These expectations reduce fears of misappropriation because transactors anticipate that others will not voluntarily engage in opportunistic behavior. Instead, exchange partners share the belief that these motives, coupled with access to private information, can enlarge the pool of potentially beneficial transactions that are not available through market means. Moreover, because the protocols of embedded ties are borrowed from the protocols of social attachments, which are learned from pre-existing structures, they are serviceable in business dealings not just as "good faith conformity" norms, but as clear expectations for a "meeting of the minds" (Macneil forthcoming). Potentially this can save on the costs of organizing other governance arrangements, freeing resources for future productive prospects (Fukuyama 1995). In this way, embedding transactions in social ties does not foreordain cooperative outcomes. Rather, it provides an essential priming mechanism that promotes initial offers of trust and reciprocity that, if accepted and returned, solidify through reciprocal investments and self-enforcement. In contrast, the expectation of avaricious actions that is anticipated in arm's-length ties is likely to prompt distrust, even if action is credible, except for discrete cases in which economic

\footnotetext{
1 The literature on attachments distinguishes between ties between persons and ties between organizations (Baker, Faulkner and Fisher 1998; Blau 1964; Levinthal and Fichman 1988; Seabright, Levinthal, and Fichman 1992) and views social attachments as personal ties (which constitute ties between the individuals' firms, even if the reverse does not hold). A social attachment is an affiliation of shared interests and fidelity that develops when behavior that is culturally associated with familiar and noncommercial transactions is enacted as part of the commercial exchange (Iacobucci and Ostrom 1996). In this study, such social behaviors include wedding invitations, parties, dining, sports competitions, shows, or other social events that both friends and businesspersons can and do commonly enact through time and that are valued in that persons share these behaviors in proprietary ways with select others.
}

incentives are aligned or third parties enforce fairness (Kollock 1994). ${ }^{2}$

Extending the above arguments to lending relationships suggests that the availability and costs of a firm's capital should vary with the degree to which its commercial transactions with a bank are embedded in social attachments. Embedded ties furnish governance and access to private information benefits that can channel resources and motivate attempts at integrative solutions to lending problems that are not available through market ties. Building on these arguments for how embeddedness affects dyadic exchange also suggests that an actor's network of ties is pertinent to the financing process. Previous research has argued that a large network of arm's-length ties to banks expands the firm's pool of potential loan offers and the firm's ability to play banks off against one another (Baker 1990; Eccles and Crane 1988). While I agree in part with this logic, my analysis of lending suggests that "shopping the market" for potential offers is an incomplete picture of the lending process. Firms secure loans and lower their borrowing costs by shopping the market for what's available and through collaborative problem-solving over terms with specific lenders. This suggests that firms embedded in networks that enable them to gather information about the range of loan deals available in a market and to access the pri-

\footnotetext{
${ }^{2}$ While my objective is to propose and investigate these processes rather than to assert their validity, much social psychological research on decision-making supports these processes. Montgomery (1998) showed how transactors who assume the identity of "friend" are likely to cooperate, while transactors who assume the identity of "businessperson" are unlikely to cooperate (even if commitments are credible) because there is no priming mechanism for trust. The logic of appropriateness, first identified by March (1994), suggests that decision-makers choose actions by asking, "Who am I and what is the appropriate action for my role?" rather than basing these actions on situation-free personal preferences. Cognitive dissonance research also finds that attitudes and interests are aligned with role behavior (Kunda 1990:484). This suggests that motives to create and share value are supported by psychological processes that are set in motion by embedding processes.
} 
vate resources of particular lenders gain premium benefits from social structure because their ability to "broker and partner" on loan deals is enhanced.

\section{ETHNOGRAPHIC FIELDWORK}

I conducted field research to help formulate my embeddedness framework. Given the scarcity of research on midmarket banking, field research furnished an empirical basis for describing the pertinent actors, resources, and relationships. It also enabled a more refined analysis of bank-borrower ties than would have been possible using coarser methodological tools, although the small sample size moderated generalizability. Field research also permitted a triangulation of theory, ethnography, and statistical analysis on lending. ${ }^{3}$

I conducted field research at 11 midmarket banks in the Chicago area, a highly competitive banking market. Table 1 describes the demographic and organizational backgrounds of my 26 interviewees and their 11 banks. My sample of interviewees typified the racial, gender, and educational profiles of bankers, who are largely white, male, and college-educated. I principally interviewed "Relationship Managers" (hereafter RMs), the bank personnel who make lending decisions and interface with clients. I also interviewed two bank CEOs and two bad-debt collectors (who deal with fraudulent clients) to understand and cross-examine the viewpoints of other types of lending officers. I focused on RMs because they make the judgments about a client's loan eligibility and consequently can reveal how social and network ties affect their lending decisions. I also reviewed Federal Reserve Bank Opinion Surveys on lending to corroborate RMs' accounts. Appendix A describes these sources and the fieldwork methodology in greater detail.

\footnotetext{
${ }^{3}$ Lending decisions are made in two stages. In stage one, a bank decides whether to offer a loan to an applicant. Loan denial reflects cases in which the bank will not raise the interest rate to make up for a bad credit risk. In stage two, the bank decides what cost of credit to charge applicants who were deemed creditworthy in stage one.
}

\section{The Social Embeddedness of Lending Relationships}

The fieldwork revealed that bankers segment the market into three strata: new corporate, midmarket, and entry-level firms. Table 2 summarizes the segments, lending practices, and bank-firm relationships in these markets. While important distinctions exist between the new corporate segment and the other two segments, RMs rarely distinguish between midmarket and entry-market clients and typically maintain ties to both types of firms in their portfolios. Thus, I treat midmarket and entry-market firms similarly in my fieldwork and control for possible differences due to organizational size in my statistical analysis.

Consistent with previous research, I found that in the new corporate segment, public and certified financial statements provide banks with ready access to pertinent information about a firm's creditworthiness (Mizruchi and Stearns 1994b). Similarly, firms use their large treasury departments to identify the lowest cost loans or to gain bargaining position vis-à-vis banks by borrowing directly from money markets. ${ }^{4}$ Thus, lending ties between big firms and banks are transactional, with banks chasing customers who treat loans and banks as commodities (Davis and Mizruchi 1999).

The social structure of the midmarket differs from the new corporate segment in ways that have important theoretical and substantive implications. Firms experience ambiguity in evaluating banks because they lack sophisticated financial expertise and are too small to borrow from money markets. Thus, they depend on banks for financial advice and credit, yet they lack the clout and financial wherewithal to ensure a bank's probity, increasing their reluctance to share private information with the bank's RMs. For example, one RM observed,

If it's company money it might be in the right pocket, if it's personal money it might be in their left pocket, but it's all in the same pair of

\footnotetext{
${ }^{4}$ Money markets sell capital directly to firms at the same rate as banks. London InterBank Offer Rate is the current money market standard for lending rates and reflects the interest rate paid on deposits among banks in the Eurodollar market.
} 
Table 1. Characteristics of Interviewees in the Field Research: Relationship Managers (RMs) at Chicago Banks, 1988

\begin{tabular}{|c|c|c|c|c|c|}
\hline \multirow[b]{2}{*}{ Bank } & \multirow[b]{2}{*}{$\begin{array}{c}\text { Bank } \\
\text { Deposits }^{\mathrm{a}} \\
\text { (in } \$ 1,000 \mathrm{~s} \text { ) }\end{array}$} & \multicolumn{4}{|c|}{ RM's Profile } \\
\hline & & $\begin{array}{c}\text { RM's } \\
\text { Sex /Race }\end{array}$ & $\begin{array}{l}\text { Number of } \\
\text { Years in } \\
\text { Industry }\end{array}$ & $\begin{array}{l}\text { Number of } \\
\text { Firms in } \\
\text { Portfolio }\end{array}$ & $\begin{array}{c}\text { Interview } \\
\text { Time } \\
\text { (in Minutes) }\end{array}$ \\
\hline \multicolumn{6}{|l|}{ Entry-Level } \\
\hline $\begin{array}{c}\text { First Bank of } \\
\text { Evanston }\end{array}$ & 104,181 & $\begin{array}{l}\text { Male/white } \\
\text { Female/white }\end{array}$ & $\begin{array}{r}17 \\
2\end{array}$ & $\begin{array}{r}21 \\
9\end{array}$ & $\begin{array}{l}60 \\
30\end{array}$ \\
\hline \multirow[t]{2}{*}{$\begin{array}{l}\text { 1st National Bank } \\
\text { of La Grange }\end{array}$} & 125,475 & $\begin{array}{l}\text { Male/white } \\
\text { Male/white }\end{array}$ & $\begin{array}{c}40+ \\
8\end{array}$ & $\begin{array}{l}50 \\
17\end{array}$ & $\begin{array}{l}120 \\
120\end{array}$ \\
\hline & & Male/white & 3 & 6 & 120 \\
\hline 1st Midwest Bank & 178,825 & $\begin{array}{l}\text { Male/white } \\
\text { Male/white }\end{array}$ & $\begin{array}{r}35 \\
4\end{array}$ & $\overline{17}$ & $\begin{array}{l}60 \\
45\end{array}$ \\
\hline \multicolumn{6}{|l|}{ Midmarket } \\
\hline \multirow[t]{2}{*}{ Bank One-Chicago } & $1,156,874$ & $\begin{array}{l}\text { Male/white } \\
\text { Male/black }\end{array}$ & $\begin{array}{r}15 \\
3\end{array}$ & $\begin{array}{l}50 \\
12\end{array}$ & $\begin{array}{l}45 \\
50\end{array}$ \\
\hline & & Female/white & 6 & 26 & 30 \\
\hline \multirow[t]{2}{*}{ Cole Taylor } & $1,327,893$ & Male/white & 20 & 54 & 45 \\
\hline & & Male/white & 5 & 13 & 50 \\
\hline \multirow[t]{4}{*}{ BankAmerica } & $3,887,571$ & Female/white & 19 & & 60 \\
\hline & & Male/white & 7 & 15 & 45 \\
\hline & & Female/white & 9 & 35 & 30 \\
\hline & & Male/white & 19 & 50 & 75 \\
\hline $\begin{array}{l}\text { American National } \\
\text { Bank }\end{array}$ & $4,357,509$ & Male/white & 9 & 25 & 50 \\
\hline \multirow[t]{4}{*}{ Northern Trust } & $6,301,607$ & Male/white & 25 & 27 & 120 \\
\hline & & Male/white & 7 & - & 60 \\
\hline & & Male/white & 5 & 8 & 30 \\
\hline & & Male/white & 15 & 19 & 70 \\
\hline \multicolumn{6}{|c|}{ Midmarket and New Corporate } \\
\hline \multirow[t]{3}{*}{ Harris Bank } & $8,653,638$ & Male/white & 7 & 21 & 60 \\
\hline & & Female/white & 9 & 18 & 55 \\
\hline & & Male/white & 12 & 14 & 45 \\
\hline $\begin{array}{l}\text { LaSalle National } \\
\text { Bank }\end{array}$ & $9,761,356$ & Male/white & 12 & 25 & 50 \\
\hline $\begin{array}{l}\text { 1st National Bank } \\
\text { of Chicago }\end{array}$ & $17,961,480$ & Male/white & 25 & 50 & 35 \\
\hline
\end{tabular}

Note: A total of 26 RMs were interviewed at 11 different Chicago banks. Interviews were conducted on site between February 1 and May 1, 1988. Interview time totalled 26 hours.

a Bank deposits came from the Bank and Thrift Branch Office Data Book (FDIC 1998).

pants. It's all their money. It's very personal to them. ... A lot of them will feel like, "We're just a small guy, they're from a big bank."

Although banks control the flow of capital, they also experience ambiguity in evaluating midmarket firms, which are typically not debt rated or certified. In particular, the bundling of the business and private lives of the firm's managers is viewed as a key source of performance ambiguity. Because the firm's capital and the entrepreneur's capital are often intertwined, banks' RMs 
EMBEDDEDNESS IN THE MAKING OF FINANCIAL CAPITAL

Table 2. Characteristics of Banks by Market Segment

\begin{tabular}{|c|c|c|c|}
\hline \multirow[b]{2}{*}{ Characteristic } & \multicolumn{3}{|c|}{ Market Segment } \\
\hline & New Corporate & Midmarket & Entry Level \\
\hline $\begin{array}{l}\text { Sales segmentation } \\
\text { and market range }\end{array}$ & $\begin{array}{l}\text {-500 million or more } \\
\text { - Multi-market } \\
\text { - Multi-product }\end{array}$ & $\begin{array}{l}\text { - } 10 \text { to } 500 \text { million } \\
\text { - Single market } \\
\text { - Single or multi-product }\end{array}$ & $\begin{array}{l}\text { - Up to } 10 \text { million } \\
\text { - Single market } \\
\text { - Single product }\end{array}$ \\
\hline $\begin{array}{l}\text { Financial market } \\
\text { intermediation }\end{array}$ & $\begin{array}{l}\text { - Firms debt rated } \\
\text { - Certified financial } \\
\text { statements }\end{array}$ & $\begin{array}{l}\text { - Firms rarely debt rated } \\
\text { - Unreliable or no certified } \\
\text { financial statements }\end{array}$ & $\begin{array}{l}\text { - Firms rarely debt rated } \\
\text { - Unreliable or no certified } \\
\text { financial statements }\end{array}$ \\
\hline $\begin{array}{l}\text { Firm's financial } \\
\text { decision structure }\end{array}$ & $\begin{array}{l}\text { - Treasury department } \\
\text { - Separation of CEO } \\
\text { and CFO positions }\end{array}$ & $\begin{array}{l}- \text { Limited or no financial } \\
\text { staff } \\
\text { - } \mathrm{CEO} \text { is owner-manager } \\
\cdot \text { No CFO }\end{array}$ & $\begin{array}{l}- \text { No financial staff } \\
-\mathrm{CEO} \text { is owner-manager } \\
\cdot \text { No CFO }\end{array}$ \\
\hline $\begin{array}{l}\text { Firm's capital } \\
\text { dependence on } \\
\text { banks }\end{array}$ & $\begin{array}{l}\text { - Firms have multiple } \\
\text { sources of external } \\
\text { financing } \\
\text { - Firms have multiple } \\
\text { sources of internal } \\
\text { financing }\end{array}$ & $\begin{array}{l}\text { - Banks are major source } \\
\text { of external financing } \\
\text { for firms } \\
\text { - Limited or no internal } \\
\text { financing for firms }\end{array}$ & $\begin{array}{l}\text { - Banks are major source } \\
\text { of external financing } \\
\text { for firms } \\
\text { - Limited or no internal } \\
\text { financing for firms }\end{array}$ \\
\hline $\begin{array}{l}\text { Role of relationship } \\
\text { manager in } \\
\text { making deals }\end{array}$ & $\begin{array}{l}\text { - Solicits requests for } \\
\text { financing from corporate } \\
\text { treasury departments } \\
\text { - Makes bids on corporate } \\
\text { offerings }\end{array}$ & $\begin{array}{l}\text { - Assesses financial and } \\
\text { managerial credit- } \\
\text { worthiness } \\
\text { - Makes loan decision } \\
\text { - Seeks loan approval } \\
\text { from bank }\end{array}$ & $\begin{array}{l}\text { - Assesses financial and } \\
\text { managerial } \\
\text { creditworthiness } \\
\text { - Makes loan decision } \\
\text { - Seeks loan approval } \\
\text { from bank }\end{array}$ \\
\hline
\end{tabular}

Sources: Ettin (1994); Berger, Kashyap, and Scalise (1995); Gorton and Rosen (1995); Federal Reserve Bulletins on bank changes (November 1996); Federal Reserve Board senior loan officer opinion surveys; and original field research.

need to assess how a client's private life affects the firm's economic performance. These social preconditions importantly affect economic exchange in this market and, in the course of everyday business dealings, also encourage discussions of private matters normally had with social attachments, deepening the embeddedness of commercial transactions between firms and banks in social attachments and networks. An RM explained,

It's something you wouldn't think ... has to do with major business, but ... [e]very social issue is played out in economic form. They [CEOs] have children of unequal talents; the CEO is less talented than the children. Somebody doesn't want to give up stock. Somebody does. . . . Can't see that on a balance sheet or P\&L [profit and loss statement]. You need to understand what's going on around the individual, ... and that plays out in "situations." That's the dynamic.

So information is not efficient, and with that comes the need for the bank to interpret... . [I]mperfect information and [the firm's] imperfect awareness of alternatives means that most conversations are negotiations because there needs to be a meeting of the minds.... You also will develop, as a byproduct of that attention, a relationship.

In a fashion analogous to how financial markets govern exchanges and certify the validity of publicly available information, the embedding of commercial transactions in social attachments and networks creates a mechanism by which to govern exchanges of private resources (Abolafia 1997). RMs refer to this process as "market making," a phrase that denotes their view of how social ties furnish governance arrangements and promote transfers of private resources, which in turn make deals that would not arise in their absence. A lead RM summarized these essential conditions:

If anybody tells you a story, it reflects their view of the world, which doesn't mean that they're lying but it's impossible to separate out the storyteller from their objectives. ... [Y]ou couldn't just say, "Oh the truth is in the financial statements." Take a company, and based 
on different accounting treatments you have different looking balance sheets. If all you did was look at the numbers, you would make different decisions on the same company! I'll ask questions about financial statements or projections or the business but getting answers is not enough. So, we need this interactive process, ... which is this digging in and recreating of something so that you understand the components. ... That's a relationship, ... a market being made.

Also consistent with embeddedness theory, I found that the degree to which interviewees embed their transactions in social structure varies. The more that commercial transactions are embedded in social attachments, the more expectations of trust govern exchanges. One RM expressed it this way:

[A] relationship [means] that you know a person like his family and you feel on a level with him-not pure friends-but that he trusts what you say. That you're taking care of him.... [So] the more I know a person, the more he understands why I'm asking these questions. He doesn't feel so defensive. Otherwise, with market ties it's a battle.

Another RM said,

A relationship on a social basis tends to break a lot of ice and develop a multidimensional relationship that's more than cold facts, interest rates, and products. It's an emotion-based bond ... that's so important to have ... [because] the customer will let us know about problems early, so we can correct them.

Other RMs noted that reciprocity characterizes embedded ties, an outcome that is bolstered by expectations of trust. As another RM explained,

On the golf course, at a ball game, or the theater, they'll let their guard down more often. We exchange information-not like a marriage-more like dating. I share information about me as a person. I let them see me and share with them our company's struggles. As I share that information, I get information back. It's kind of a quid pro quo.

A distinctive aspect of the embedding of commercial transactions in this market is that they often have properties of extended closure that promote the creation of a common set of inferences among the members of a network. These properties of closure arise when RMs and entrepreneurs form direct relations with third persons, such as spouses and children, which entrepreneurs and RMs confidentially rely on for perceptions of character and trustworthiness in their business dealings with others. By enclosing private and public information flows in a matrix of social ties, shared expectations and regularized behavior arises not through the enforcement by a third-party, such as the courts, but through unanimity of inference. This unanimity of inference is important for undertaking risky actions, such as estimating credit eligibility or long-term returns on loans, because it reduces the perceived uncertainty associated with estimating an actor's most likely behavior. In its application and consequences, this property combines the consequences of network closure typically found within common social groupings (Coleman 1988 ) with the purposeful multivocal strategies used by the Medici to interlock the economic and personal fates of Florentine merchants and bankers (Padgett and Ansell 1993). A key difference is that the Medici constructed this closure through formal marriages and contracts, whereas modern-day bankers achieve similar governance outcomes by organizing informal social events that promote relationship-building among RMs, entrepreneurs, and their significant others. Tom, a lead RM at a large midmarket bank, described the process of enclosing social ties so that they crisscrossed the personal and business networks of entrepreneurs, increasing the embeddedness of the tie between the banker and entrepreneur and the uniformity of inference about the banker's credibility. Here Tom refers to his client, Jim, Jim's spouse, Ellen, and the consequences for governance of this type of embedding:

For Ellen to tell Jim, "You know, that Tom, I really like him and I trust him a lot," has more impact on his view of me than if his controller told him that. It's sort of the old Nancy Reagan "pillow talk" thing with Ron. They're integral to their spouses' decisions. Getting to know them and having them get to know you, bridges those personal things that you talk about and know about them. And the web gets woven deeper in terms of the personal side.

While these results illustrate the prevalence and material consequences of embedded ties, my fieldwork revealed that embedded relations retain "passions" that are uncharacteristic of the antipathy of arm's- 
length transacting (Hirschman 1977). Even if embedding is initiated for governance and access benefits, the resulting intimacy imbues the relationship with expressive value that is separate from purely material stipulations, even if it impinges upon them. For example, one RM declared,

[Y]ou have to maintain that professional distance because you never know when you're going to have to make that tough call [i.e., risk losing the attachment over a business difference]. But having said that, ... I have clients that I'm very close with, and in most circumstances it helps. I know their kids' names and when their kids have the flu. I go out socially with my wife and with them and their spouses.

Another RM explained how embedding spontaneously infuses a business tie with social values and attitudes that would be irrelevant in the market model:

After he [the entrepreneur] becomes a friend, you want to see your friend succeed and that goes along many lines. If I can be a part of helping them do that, it's a real good feeling and I'm providing a service not only to them but their employees.... So there's a lot of things that you kind of from a moral standpoint take into effect... . That is kind of a side effect of your relationship.

By contrast, arm's-length ties lack the expectations of trust and reciprocity needed for knowledge transfer and collaboration, resulting in different economic consequences. For example, one RM described how arm'slength ties might be effective at governing price data across different banks but are poor governance arrangements for imbuing information with credibility or transferring private information. He said,

Firms got to get comparative information, ... [but] oftentimes entrepreneurs will negotiate with you and they'll tell you they've got a deal from somebody else and they don't. That's part of where that honesty and integrity and being able to trust the people that you're dealing with becomes very important.

Another RM stated that arm's-length ties put

. . . a relationship out for bidding. Every opportunity a customer has to get credit they'll shop your deal. [They'll say], "I've talked to a couple other banks and they're willing to give me this." .. . It's price oriented. . . . [If] I ask questions about performance, the client is aggressive and that's not fun.

\section{RELATIONAL EMBEDDEDNESS AND LOAN ACQUISITION AND COSTS}

How do these properties of embeddedness affect an organization's cost and acquisition of capital? I argue that embedded ties both create value in the dyad and motivate exchange partners to share that value. Focusing on the mechanisms by which value is created and shared from the firm's perspective, the two most relevant processes have to do with the creation of contingent contracts and the leveraging of social capital from one RM to another RM on behalf of the firm. ${ }^{5}$ The high level of trust in the relationship enables firms and banks to negotiate contingent loan agreements. A contingent loan agreement converts a loan with a homogeneous price structure into a loan that has separate components and a tiered price structure. A gradient of prices and terms in a contingent agreement enables a firm to start with and maintain low capital costs and few loan restrictions so long as it sustains a preset level of performance, thereby enhancing its credit eligibility and reducing its borrowing costs relative to one-cost, one-structure loans. By contrast, loans negotiated through arm'slength ties often have homogeneous structures because there is no basis of trustworthiness on which to estimate how credit risks can be assessed relative to the firm's promises to repay. A case often recounted by RMs concerned attempts to structure loans in ways that gave firms the benefit of the doubt contingent on the interpretation of ambiguous performance data that would otherwise result in loan denial, an unfavorable rate, or tight restrictions. Using a contingent agreement, RMs might offer, for instance, a low interest rate the first year that would rise in subsequent years only if the firm failed to maintain its projected performance level. Remarkably, this specification of the contingent ordering of the risk inherent in the loan deal was often predicated on the level of trust and

\footnotetext{
${ }^{5}$ Embeddedness creates value for banks by enhancing their ability to reduce the costs of writing loan contracts, to retain clients, and to decommodify financial capital. These processes and their effects on the bank's profit spread and contractual restrictions on a loan are explored in Uzzi (1999).
} 
reciprocity in the relationship rather than on comparative information that appeared in public financial statements. In particular, the trust and reciprocity of embedded ties enhanced the transfer and credibility of the private information that was essential to the creation of a unique contingent loan agreement for the firm. A lead RM explained how his embedded tie to an entrepreneur motivated an integrative solution to the firm's credit request through the design of a specialized contingent contract, which resulted in better access and lower costs than arm's-length relations could have provided:

[B]ecause we knew this guy [I said], ... "Tell you what we'll do: We'll give you a price of $X$ today. We'll base our pricing as if those expenses were not in your financial statements. ... But after 12 months, ... if it's all flushed through you will continue on in this price level. If you don't, boom, your pricing will go up." So, because of the relationship, because we knew the guy and we really believed in him and trusted him, we gave him the benefit of the doubt on the pricing for the first year. He has to continue to perform or it goes up. So, that's a way we would sort of marry the two, the objective and the subjective, if you will.

Embedded ties also benefit firms by motivating bankers to leverage their personal social capital at the bank on the firm's behalf. Unlike the advantages described above, these outcomes are not necessarily attempts to affect the loan's tangible features. Rather, RMs use aspects of their social capital within the bank, such as their reputation or social ties to other RMs, to influence the expectations of other relevant bank decision-makers regarding a firm's creditworthiness. I observed a similar phenomenon (Uzzi 1996) when I found that the expectations of trust and reciprocity between two economic actors could be "rolled over" to a new third party, thereby establishing trust and reciprocal obligations between two parties that lacked a prior history of exchange. In an analogous process, RMs seeking to act on a firm's behalf primed first-time introductions between other RMs and the firm's managers with expectations of trust-extending the web of shared beliefs about the firm's creditworthiness to other relevant bank decision-makers. One RM described how these factors can play out for a firm in a deal in which its creditworthiness is indefinite. In particular, she noted how her reciprocal obligee to the entrepreneur and the entrepreneur's personal expression of need induced her to pledge her social capital at the bank on the firm's behalf, despite the performance ambiguity reported in the firm's financial statements:

[T] he deal on paper is a tough deal. And he [the CEO] said, "I'm fucking scared." I said, "Okay, as long as I know where you stand." .. . Well, obviously that's a long way from I'm fucking scared to there's a deal here. [So], I go to my president and we go through the credit risks. I said, "All the credit risks are blatantly obvious. ... He said, "Well, how do you overcome it?" [I said], "We've got to go see the business and meet the people." And he agreed and said, "Then I want to see the business and meet the people." Now, I can't control what his "gut" is going to be. But I know the principals of the firm, a regional credit officer who's chairing up a loan committee, my President and senior lender. [So], it's got to be a real bad credit for them to say no, especially when I have a 40-percent growth markup.

These arguments and findings illustrate patterns of relational embeddedness and how it operates even in well-developed financial markets by positively affecting a firm's ability to acquire capital and lower its cost of capital. Embedded ties generate surplus value for the firm by promoting private information and resource transfers that create value and motivate banks to share the value created in the relationship with the firm. Therefore, based on my framework and fieldwork, I expect statistical analysis to support the following hypotheses:

Hypothesis 1: The more a firm's commercial exchanges with a bank are embedded in social attachments, the more likely the firm is to acquire financing at that bank.

Hypothesis 2: The more a firm's commercial exchanges with a bank are embedded in social attachments, the lower the firm's cost of financing at that bank.

\section{STRUCTURAL EMBEDDEDNESS AND LOAN ACQUISITION AND COSTS}

My argument has focused on the properties and consequences of dyadic bank-firm social attachments, yet dyadic exchanges reside 
within a larger network of ties that amplifies or diminishes their benefits. Some finance and organization theories hold that firms with expansive networks of arm's-length ties to banks optimize their bargaining power and provide access to a large pool of price and loan possibilities, thereby increasing their chances at getting corporate financing (Mintz and Schwartz 1985; Petersen and Rajan 1994). My argument about network structure partly agrees with these theories, but focuses on the organization rather than on network size as the operative mechanism. Although an expansive network of arm's-length ties can enable a firm to effectively scan the market for deals and help broker information among banks, it lacks the embedded ties that facilitate partnering. Conversely, while embedded ties promote collaboration, a network composed only of embedded ties could induce overattentiveness to local resources and historical conventions, limiting a firm's access to market information and new ideas. This suggests that a network composed of both embedded ties and arm's-length ties can moderate the shortcomings of each type of tie while preserving their strengths, optimizing the firm's range of available action.

Building on prior research (Baker 1990; Uzzi 1996, 1997), I refer to a network's ability to synthesize the benefits of different types of ties as network complementarity. Networks high in complementarity produce premium outcomes because the features of different ties reinforce one another's advantages while mitigating their disadvantages. Thus, while I argue that embedded ties provide special informational and governance benefits with a specific lender, I acknowledge that a firm that maintains a network composed only of embedded ties risks suboptimal network-level outcomes by not capitalizing on the properties of network complementarity. ${ }^{6}$

\footnotetext{
${ }^{6}$ My concept of network complementarity builds on portfolio theory, which argues that assets in a portfolio have a contingent value that depends on the other assets in the portfolio, not just the properties of the individual asset. In a similar manner, a tie's value is greatest when other types of ties complement its strengths, while the entire portfolio's value rises if the benefits of the different types of ties that compose the portfolio do not coincide. In this context, a
}

Heterogeneity in the market for loans suggests that networks high in complementarity should enhance a firm's ability to get financing and lower its financing costs. Access to capital grows with a firm's ability to (a) shop the market for a loan structure that is compatible with its credit profile and (b) partner with a bank on the customization of a loan structure that fits its credit profile. Thus, high network complementarity should enhance a firm's access to capital by promoting both brokerage and partnering benefits. In my fieldwork, the dual benefits of networks high in complementarity were manifested in several ways. Bankers noted that firms with networks high in complementarity used their arm's-length ties to scan the market for differences in loan prices and structures. That information was then transferred to their close lender through an embedded tie, which imbued market data and unfamiliar loan stipulations with credibility and motivated the lender to use novel market data to the mutual benefit of the firm and bank. In this way, firms with networks of embedded ties and arm's-length ties combined the partnering benefits of embedded ties with the brokering benefits of arm's-length ties.

In an example of this process, an RM recounted the dynamics of a recent deal in which his bank was one of the arm's-length ties in the network of a firm seeking corporate financing. He noted how the entrepreneur used an arm's-length tie to his bank to access information about his bank's loan prices and structures. The entrepreneur then disclosed that information to his close lender, which customized a deal for the firm using the bank's distinctive capabilities and resources and the novel loan ideas of other banks that the entrepreneur had accumulated through its arm's-length ties. What's more, the RM observed that the embedded tie between the entrepreneur and his bank was the main source of both the trust and reciprocal obligations needed to customize deals that benefit from a

network refers to the firm's ego network of direct ties to banks, not the aggregation of all bank-firm networks in an arbitrary region or industry boundary. Previous research has also referred metaphorically to ego networks as portfolios (Powell, Kopub, and Smith-Doerr 1996:120). 
synthesis of market information and exclusive private resources. The RM reported:

Three banks were pitching on the same deal, and the company said to me "give us a creative idea on how you would structure this financing." [W]e provided a very creative idea with term loans and revolving credit [factors affecting price and structure]. They said, "We really like this structure, but X has been our bank for 50 years and we don't want to pull the agency from them." When the term sheet came back from X bank, X bank had basically our term sheet with their name on it. Later, the CFO said to me, ... "Look, you guys came up with the idea. So, we'd like to give you the first shot at our trust business or the private banking of the owners" [a conciliation prize for providing valuable ideas]. So, we gave the banking insight on the marketplace to the firm [but lost the deal].

The above argument and data suggest that networks high in complementary produce premium benefits by preserving the strengths and diminishing the weaknesses of different types of ties. In the context of corporate financing, complementarity increases a firm's ability to broker market information and instigate partnering around custom deals by drawing on both the novel information that is dispersed among players in a heterogeneous market and the private resources obtained through relationships. Thus, based on my framework and the fieldwork data, I expect statistical analysis to support the following hypotheses:

Hypothesis 3: A firm's likelihood of acquiring financing increases when it has a network with an integrated mix of embedded ties and arm's-length ties and decreases when it has a network that tends toward either solely embedded ties or solely arm's-length ties.

Hypothesis 4: A firm's cost of financing decreases when it has a network with an integrated mix of embedded and arm'slength ties and increases when it has a network that tends toward either solely embedded ties or solely arm's-length ties.

\section{DATA AND METHODS}

I tested my hypotheses using data from the National Survey of Small Business Finances, a survey administered by the Federal Reserve Bank to investigate how market and organizational characteristics affect capital costs and availability. This in-person survey collected data on firms' lending ties, sources of financing, loans, and organizational and financial characteristics. The random sample consisted of 1,875 corporations and 1,529 partnerships/sole-proprietorships with up to 500 employees and $\$ 154$ million in assets, operating in 1989 in the U.S. nonagricultural sector. Depending on the item, the response rate was 70 to 80 percent, reducing the sample size to about 2300 cases. Nearly 90 percent of the businesses were owner-managed; 12 percent were owned by women and 7 percent were minority-owned.

\section{Dependent Variables}

The two dependent variables I examined correspond to the first and second stages of the corporate financing process. The first stage concerns whether a firm acquires capital (i.e., a loan). The standard assumption in lending research is that small- to medium-sized firms constantly need credit. Consequently, the lack of a loan suggests that a firm was denied credit or offered unattractive loan agreements, which in effect informally counsel applicants to withdraw their requests, making self-restricted consumption tantamount to denial of a loan (Lummer and McConnell 1989; Munnell et al. 1992). Given these complexities, most research cannot fully determine whether a lack of a loan is due to credit rationing by the bank or to the firm's selfrestricted consumption. Hence, research generally adopts the convention that if a firm's need for credit is controlled for, firms without loans were probably denied credit (Cole and Wolken 1995; Hawley and Fujii 1991). Given that my data coincide with previous research in this area, I followed the above convention, defining a firm as credit accessed (coded 1) if it obtained a loan between 1987 and 1989 (coded 0 if not). This approach allowed me to extend prior research, even if a judicious interpretation of this stage of the model's results were called for. Stage two estimates the cost of capital, which I defined as the interest rate on the firm's loan - the typical measure used in research and practice on lending (Petersen and Rajan 1994). 


\section{Independent Variables}

A methodological issue concerns how to create valid quantitative measures that capture the dimensions of the ethnographic findings and yet are parsimonious and amenable to statistical analysis. Using Miles and Huberman's (1994) and Bollen and Paxton's (1998) methods, I applied techniques that look for convergence among theory, face validity, and discriminant validity. In these methods, validity increases if independent sources of theory and evidence converge on a consistent pattern and discriminate among other concepts. $^{7}$

Prior research holds that embedding increases with the duration of the relationship and the multiplexity of the relationship (Blau 1964; Gulati 1994; Lazerson 1995; Larson 1992; Lin, Ensel, and Vaughn 1981; Marsden and Campbell 1984; Seabright et al. 1992). Time in a relationship permits network partners to learn about and share private information, incur debits and credits in the relationship, form bonds of trust, and exploit opportunities for reciprocity. Seabright et al. (1992) operationalize a social attachment between an auditor and a $\mathrm{CEO}$ as "the length of time the individual engages in activities associated with the relationship ... [the strength of the social attachment] is likely to increase with the years of tenure that have elapsed since the formation of the interorganizational relationships" (pp. 133-34). They also operationalize attachment strength between an auditor and a CEO as the multiplexity of overlapping roles they interfaced around (CEO, CFO, or CAO).

\footnotetext{
${ }^{7}$ Triangulation determines the validity of constructs by looking for convergence in the outcomes of different methods. As with some other psychometric methods (e.g., factor analysis), no formal statistical tests are involved. Triangulation works by demonstrating that a measure accurately represents the construct even if some nuances are omitted in the same way that econometric models do not explain all the variance. Moreover, the weaknesses of this method are not unique, but are part of a class of statistical problems that introduce measurement error into network variables. Thus, since measurement error normally attenuates estimates, tests of hypotheses are conservative (McPherson, Popielarz, and Drobnic 1992).
}

I looked for convergence between my theory, prior operationalizations, and the accounts of RMs (i.e., face validity) by asking RMs about how embedded ties could be operationalized and distinguished from other quantitative measures of the bank-firm relationship (i.e., discriminant validity). For instance, I probed RMs with inquiries such as, "If you want to determine if your colleague has a close tie with a client like the one we have been discussing, what quantitative information would you use or look for?" Consistent with research, RMs independently stated that sound measures of embedded ties included (a) the duration of the relationship and (b) the multiplexity of the relationship between the lender and the firm. Thus, I defined the duration of the relationship in years and the multiplexity of the relationship as the number of business services (e.g., cash box services, wire transfers) and personal bank services (e.g., personal bank accounts, wills, estate planning) used by the entrepreneur. Business and personal services included brokerage, capital leases, cash management services, credit card receipt processing, letter of credit, night depository, pension fund, personal estate planning, trusts, retirement planning, revolving credit arrangements, money/ coins for operations, and wire transfers. Finally, I performed discriminant validity checks by inquiring if these indicators might also measure lower loan production costs. RMs said these factors lowered transaction costs and increased retention, but they did not directly lower the costs of administering a loan. One RM stated, "It doesn't make it less expensive to manage a tie the longer it's around because some long-term clients want to see the banker every month or utilize the bank's services where that gets expensive."

I used the same method to construct my measure of network complementarity, which operationalizes the degree to which a firm uses arm's-length ties, embedded ties, or a mix of ties to transact with the banks in its network. (Here, the term network refers to the egocentric network of direct ties between a firm and all its banks, not just the lending bank.) Baker (1990) shows that a Herfindahl index, a relative of the Gibbs-Martin index of social heterogeneity (Blau and Schwartz 1984), parsimoniously measures the mix of different types of ties in a firm's network. 
The index varies between greater than 0 and less than or equal to 1 . As the index nears 0 , a firm disperses its transactions among many banks through arm's-length ties; as it nears 1 , a firm consolidates its transactions with one or few embedded ties. At intermediate values, a firm has an integrated mix of embedded ties and arm's-length ties. In the analysis, I used a linear and quadratic term to capture these curvilinear effects. The measure is defined as $\Sigma\left(P_{j}^{2}\right)$, where $j$ varies from 1 to $N$ banks, and $P_{j}$ is the proportion of the firm's banking business that is dedicated to bank $j$. I defined $P_{j}$ as the sum of three fundamental accounts - savings, checking, and line-of-credit accounts-that RMs used to indicate the intensity of exchange between a firm and a bank. For example, if a firm used three banks and apportions 70 percent of its business to bank one, 20 percent to bank two, and the remaining 10 percent to bank three, then its network structure score is equal to $(.70)^{2}+(.20)^{2}+(.10)^{2}=.54$. One potential shortcoming of this measure is that it is difficult to compare across cases if the sizes of the firms' banking networks vary widely. Because midmarket firms vary but not excessively in the size of their banking networks, I directly controlled for network size in the regressions.

Consistent with the assumptions of my measure of network complementarity, interviewees stated that firms that consolidated their banking with one bank tended to embed their commercial transactions in social attachments. In contrast, interviewees revealed that firms that dispersed their banking transactions tended to have arm's-length ties and that at least occasional arm's-length business at the bank was a prerequisite for them to respond to clients' requests for information on loan pricing or structures. (RMs rarely supplied similar information to customers without at least an arm's-length tie, such as cold-callers, that RMs considered to be nonrelationships.) Finally, to examine the discriminant validity of this measure with measures of resource dependence, I asked bankers whether their willingness to collaborate was motivated by reciprocal obligations and trust or dependence on a firm's business. They declared that banks rarely feel dependent on any one firm's business, particularly in this banking market segment where banks are larger than firms. Thus, this measure has the advantage of summarizing the level of the embeddedness of a firm's ego-network in one measure that has high face validity and precedent in studies of banking.

\section{Control Variables}

I controlled for the organizational, market, and loan characteristics known to affect corporate financing using the standard measures applied in prior research (Cole and Wolken 1995; Mizruchi and Stearns 1994a). Organizational controls included number of employees, organization age, log of sales change (current year minus previous year), corporate status $(1=$ yes $)$, and cash on hand, which controlled for the firm's need for credit. I controlled for the firm's ability to convert assets into cash and to carry debt using the firm's acid ratio ([current assets - inventory]/current liabilities) and debt ratio (total liabilities/total assets), respectively. To control for gender and racial discrepancies in credit decisions (Arrow 1998), I defined a firm as women-owned ( 1 = yes) or minorityowned $(1=$ yes $)$ if it had 51 percent or more ownership by women or minorities (the survey did not collect the exact percent). To control for the size of a firm's ego-network for banking, I created network size, a count of the number of financial institutions a firm uses for financial services. This variable is highly correlated with more complex indices of network structure, thus furnishing a reasonable proxy for size and degree measures of network structure that my data did not allow me to construct (Borgatti 1997).

To control for the loan characteristics that affect lending, I measured the prime rate (the interest rate to which loans are pegged) at the month and year the loan was granted. Term structure spread was defined as the yield on a government bond of the same maturity of the loan less the Treasury bill yield and accounts for interest rate differences that vary with the loan's maturity (Petersen and Rajan 1994: 13). Two indicator variables, collateral ( 1 = yes) and fixed-rate loan ( 1 = yes) controlled for systematic differences in interest rates for loans that require collateral or that have fixed rather than variable rates. Bank competition in the firm's locale was measured using the Federal Reserve's bank con- 


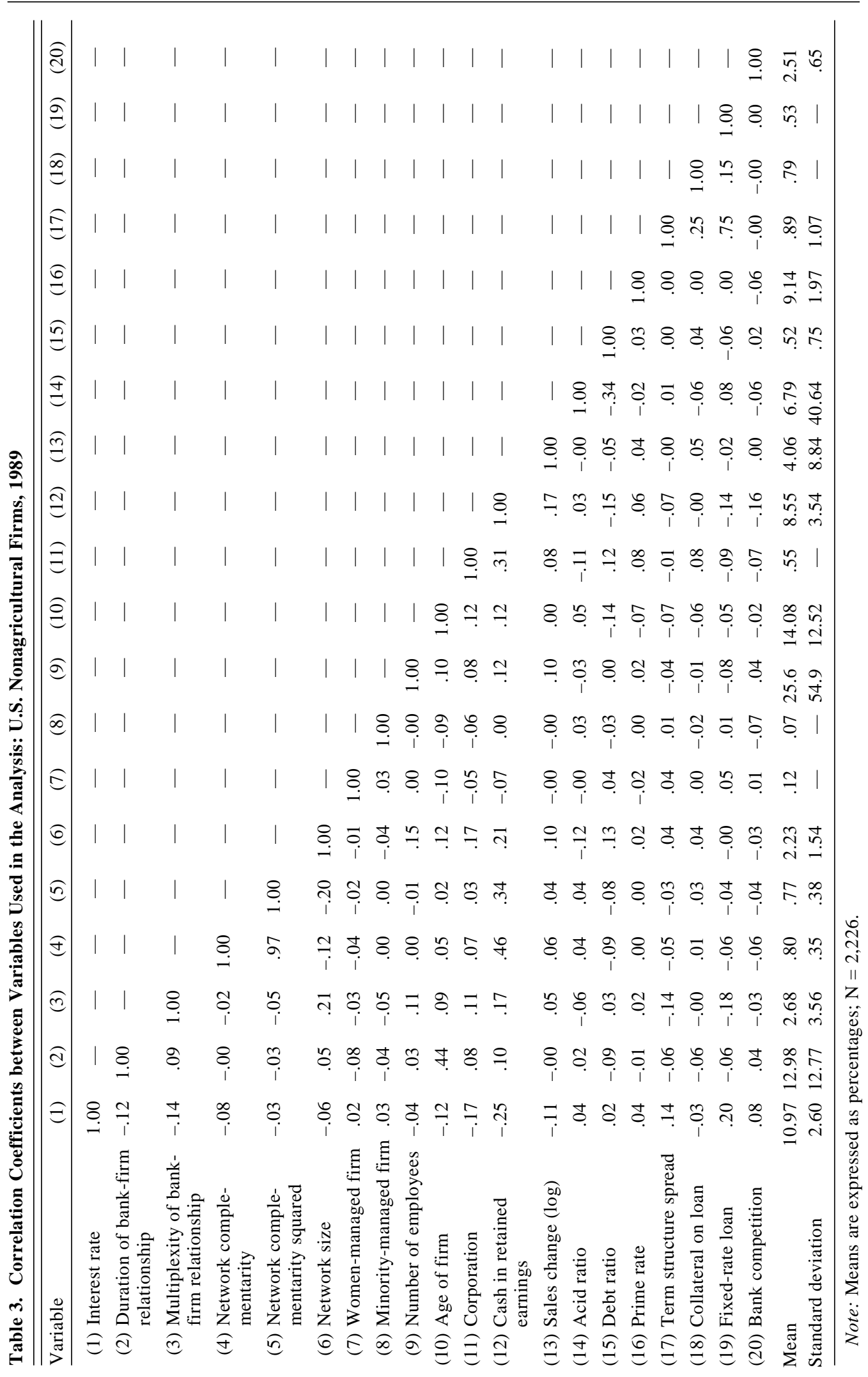


centration index $(1=$ high concentration, $2=$ moderate concentration, and $3=$ low concentration). In the analysis, I reversed the scale of this variable so that higher values correspond to greater bank competition. This measure captures both the market pressures on banks to offer favorable interest rates and the range of interest rates in a market (Petersen and Rajan 1995). Differences in interest rates in the Northeast, North Central, South, and West were controlled for with four regional indicators; industry differences were controlled for with seven industry indicators using two-digit SIC codes (lowest level of disaggregation in the data). Table 3 reports the correlations and descriptive statistics for the variables used in the analysis.

\section{Statistical Model}

I modeled the effect of social ties and networks on the acquisition and cost of capital with a Heckman two-stage selection model (Heckman 1976). This model is used when one dependent variable (e.g., the cost of capital) depends on another dependent variable (e.g., having a loan). The first stage is a probit regression that models whether the firm accessed credit. The second stage is an OLS regression that uses the estimated Mills ratio from the first stage to account for selection bias in estimating the interest rate on the outstanding loan. If regressions were run on the firms with loans, it could produce biased results if access to capital was not random. Fitting variables that correlate with access to credit but not with the interest rate helps solve the problem. Thus, I chose variables for each stage based on previous research and on my fieldwork (Mizruchi and Stearns 1994b; Petersen and Rajan 1994). ${ }^{8}$

\footnotetext{
${ }^{8}$ I checked my model specifications by estimating the interest rate and an interest rate deviation score (firm's interest rate minus the prime rate) with nested OLS regressions. While OLS does not handle selection error, it allows subsets of variables to be entered separately - a nested procedure that tends to bias the Heckman model, which is sensitive to specification error. I also examined possible distributional artifacts. I truncated the duration variable at its 95 th percentile to test for sensitivity to distributional extremes. I ran separate models with multiplexity dichotomized (no services versus one service versus mul-
}

\section{RESULTS}

Table 4 presents the results of the selection model, which examines the correlates of the acquisition (Model 1) and cost of corporate financing (Model 2). The control variable effects are noteworthy because they establish a baseline for gauging the effects of social structure and the appropriateness of the model's specification. Consistent with previous research, Model 1 shows that organizations are more likely to access credit if they are younger, have liquidity, have a noncorporate form, and are located in regions with low bank competition or low credit costs; Model 2 shows that large firms and firms with increasing sales, variable rate loans, or loans with collateral have lower costs of capital (Petersen and Rajan 1994).

In Model 2 however, it is somewhat surprising that prime rate and term structure spread had null effects. In a post hoc analysis, I dropped the fixed-rate loan variable from the regression equation to see if it was capturing the effects of these variables. As expected, prime rate had a positive effect and term structure spread had a negative effect on the cost of capital when this fixed effect was removed from the equation. Also of substantive importance is the finding that women-owned, and to a lessor degree minority-owned firms (significant at the $p<.05$ level in a one-tailed test), are less likely to access credit than firms managed by white males. The discrepancy among these social categories is significant because access to capital may be more critical than its cost, particularly to liquidity-sensitive small firms. Taken together, these results suggest that the models are adequately specified and that the embeddedness measures capture net effects not explained by current financial theory.

Hypotheses 1 and 2 predicted that relationship duration and relationship multiplexity increase a firm's probability of access to

tiple services). I ran models on the subset of data where network complementarity was not equal to 1 to investigate whether the effects were sensitive to observations where network complementarity is equal to network size because the firm uses just one bank. The results were substantively identical to those reported in Models 1 and 2 , supporting my specifications. 
Table 4. Coefficients from the Heckman Selection Regression of Access to Credit and Interest Rate on Loan on Selected Independent Variables: U.S. Nonagricultural Firms, 1989

\begin{tabular}{|c|c|c|c|c|}
\hline \multirow[b]{2}{*}{ Independent Variable } & \multicolumn{2}{|c|}{$\begin{array}{c}\text { Model } 1 \\
\text { (Credit Accessed) }\end{array}$} & \multicolumn{2}{|c|}{$\begin{array}{c}\text { Model } 2 \\
\text { (Cost of Capital) }\end{array}$} \\
\hline & Coefficient & S.E. & Coefficient & S.E. \\
\hline Constant & $1.164^{* *}$ & $(.184)$ & $11.233^{* *}$ & $(1.155)$ \\
\hline \multicolumn{5}{|l|}{ Embeddedness } \\
\hline Duration of bank/firm relationship & -.001 & $(.002)$ & $-.013^{*}$ & $(.005)$ \\
\hline Multiplexity of bank/firm relationship & .005 & $(.008)$ & $-.042^{*}$ & $(.018)$ \\
\hline Complementarity of firm's bank network & $1.772^{*}$ & $(.547)$ & $-6.275^{* *}$ & $(1.134)$ \\
\hline$(\text { Complementarity of firm's bank network })^{2}$ & $2-1.119^{*}$ & $(.461)$ & $5.030^{* *}$ & $(.960)$ \\
\hline Size of firm's bank network & $.133^{* *}$ & $(.020)$ & .039 & $(.053)$ \\
\hline \multicolumn{5}{|l|}{ Organizational Characteristics } \\
\hline Women-managed firm & $-.189^{*}$ & $(.086)$ & .020 & $(.221)$ \\
\hline Minority-managed firm & -.180 & $(.107)$ & .371 & $(.288)$ \\
\hline Number of employees & .001 & $(.001)$ & $-.002^{*}$ & $(.001)$ \\
\hline Age of firm & $-.007^{* *}$ & $(.002)$ & - & - \\
\hline Corporation & $-.132^{*}$ & $(.063)$ & - & - \\
\hline Cash in retained earnings & -.023 & $(.013)$ & - & - \\
\hline Sales change $(\log )$ & .005 & $(.003)$ & $-.022^{* *}$ & $(.007)$ \\
\hline Acid ratio & $-.025^{* *}$ & $(.004)$ & $.028^{*}$ & $(.015)$ \\
\hline Debt ratio & .004 & $(.038)$ & .070 & $(.150)$ \\
\hline \multicolumn{5}{|l|}{ Loan Characteristics } \\
\hline Prime rate & - & - & .155 & $(.096)$ \\
\hline Term structure spread & - & - & -.020 & $(.106)$ \\
\hline Collateral on loan & - & - & $-.393^{*}$ & $(.175)$ \\
\hline Fixed-rate loan & - & - & $.709^{* *}$ & $(.207)$ \\
\hline \multicolumn{5}{|l|}{ Region and Industry Indicators } \\
\hline Bank competition & $-.140^{* *}$ & $(.043)$ & .193 & $(.111)$ \\
\hline Northeast & $.264^{* *}$ & $(.082)$ & - & - \\
\hline North Central & $.211^{* * *}$ & $(.085)$ & - & - \\
\hline South & $.138^{*}$ & $(.081)$ & - & - \\
\hline Mining & .257 & $(.316)$ & - & - \\
\hline Construction & .104 & $(.093)$ & - & - \\
\hline Manufacturing & -.063 & $(.097)$ & - & - \\
\hline Transportation, communication, public utilit & ities .124 & $(.164)$ & - & - \\
\hline Wholesale trade & -.004 & $(.070)$ & - & - \\
\hline Retail trade & .178 & $(.141)$ & - & - \\
\hline Wald $\chi^{2}($ d.f. $=16)$ & \multicolumn{4}{|c|}{$131.31^{* *}$} \\
\hline Log-likelihood & \multicolumn{4}{|c|}{-3363.2} \\
\hline Rho & \multicolumn{4}{|c|}{-.352} \\
\hline
\end{tabular}

Note: $\mathrm{N}=2,226$.

${ }^{*} p<.05 \quad{ }^{* *} p<.01 \quad$ (two-tailed tests) 
credit and lower their cost of capital. Consistent with Hypothesis 2, Model 2 shows that the duration of the relationship and multiplexity of the relationship have large and significant effects on reducing the cost of capital net of standard market, firm, and loan control variables. Furthermore, the consistent effects of both independent variables suggest that they capture a similar underlying construct net of each other's effects. In real terms, the coefficients in Model 2 indicate that an additional year in a relationship lowers a firm's interest rate by 1.3 basis points (.013 percentage points), while an additional dimension (service) of multiplexity lowers a firm's interest rate by 4.2 basis points (.042 percentage points). In this market, such interest rate reductions are significant and underscore the importance of relational embeddedness relative to conventional financial and organizational factors that affect interest rates.

Inconsistent with Hypothesis 1, neither duration of the relationship nor multiplexity of the relationship affect the probability of accessing credit. These null effects indicate that while the quality of a relationship can influence the competitiveness of a rate, it is unrelated to whether or not a firm "passes the bar" for credit eligibility. This suggests that relationships influence market allocation once a firm has been deemed creditworthy but does not independently influence whether a firm is categorized as credit eligible. This inference fits with my interview data, which indicated that there is a level of risk at which banks deny loans, even if they are close to the client, because no level of confidence in the client's competency can offset the credit-carrying shortfalls that emanate from other business factors. Thus, it appears that long-term and multiplex ties influence the "pricing" decision only if creditworthiness has been established by other factors, some of which are financial and others of which are sociological.

Consistent with Hypothesis 3 and 4, network complementarity improves a firm's access to credit and its cost of capital. In Model 1 , the linear coefficient is positive and the squared coefficient is negative. Conversely, in Model 2 the linear coefficient is negative and the squared coefficient is positive. Thus, as hypothesized, networks composed of an integrated mix of embedded ties and arm'slength ties increase access to capital and reduce capital costs relative to networks composed predominantly of arm's-length ties or embedded ties. These results suggest that the complementarity of different types of ties in a network produce optimal benefits relative to networks that lack complementarity.

This conclusion is strengthened by the effects of network size on credit access and credit costs. In Model 1, network size increases the propensity for credit accessibility. This is consistent with my argument and field data that indicate that arm's-length ties increase a firm's knowledge of market innovations and the availability of different loans and pricing. Taken at face value, a larger network is better than a smaller network for access to credit. However, if price is a factor, the null effect for network size in Model 2 indicates that network size does not reduce pricing. This suggests that increases in the number of arm's-length ties to banks can help firms shop the market for loan availability but appear to ineffectively motivate banks to incorporate rivals' prices or to cut prices on a loan. Consistent with this inference, several RMs recounted situations in which a firm linked to them by an arm's-length tie applied for a loan, and because of the RMs' desire to be competitive with the firm's other banks they offered a loan but at a high, unattractive price (Uzzi 1999). Another effect that supports this line of inference emerged from a post hoc analysis of the employment sizes of firms with networks high in complementarity. The analysis showed that firms with integrated networks were larger than firms with embedded networks, but did not differ in size from firms with large arm's-length networks. This further suggests that the effect of network structure is not a proxy for firm size, but is an effect of the social organization of the ties in the firm's network. I infer that large networks of arm's-length ties effectively garner public market data but are comparatively less effective than embedded ties at promoting the trust and reciprocity that facilitate deal-making and innovation. Thus, networks high in complementarity seem to provide premium benefits by providing a bridge for integrating the public information found in markets with the private resources of particular relationships. 


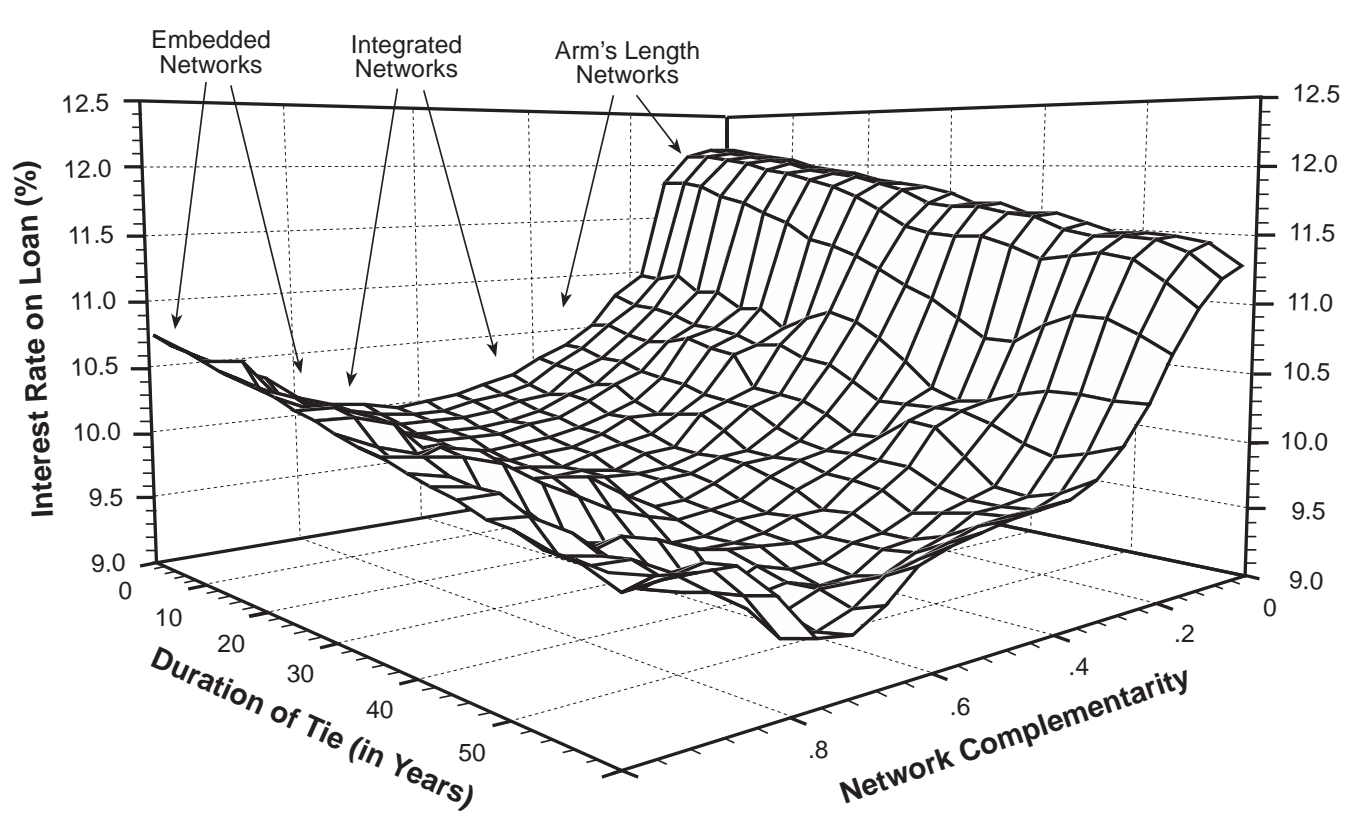

Figure 1. Social Embeddedness and the Firm's Cost of Financial Capital: U.S. Nonagricultural Firms, 1989

Figure 1 illustrates the combined effects of embeddedness in a three-dimensional surface plot that was generated holding the other significant variables in Model 2 at their means. The plot shows the interplay between relational embeddedness, structural embeddedness, and the magnitudes of three effects related to the cost of capital. First, firms that maintain integrated mixed-mode networks (the trough of the curve area) lower their cost of capital, an effect that increases linearly as the duration of the relationship between the bank and firm increases. Moreover, a proper level of network complementarity lowers the cost of capital below that of either embedded-tie networks or arm's-length networks by up to 3.0 percentage points, or 300 basis points (the difference between the U-shaped curve's right-hand tails and the trough). In terms of dollars and cents, this difference is substantial: a $\$ 100,000$ loan at 8.5 percent interest and a 10-year maturity has a final cost of $\$ 226,098$. In contrast, the same loan with an interest rate of 11.5 percent has a final cost of $\$ 296,994$. Thus, a 3-percent or 300 basis point difference in the interest rate results in savings of $\$ 70,896$ over the life of the loan. Second, consistent with my argument, the difference in the right and left tails of the U-shaped curve indicates that while neither an embedded-tie network nor an arm's-length network is as beneficial as a mixed-mode network, an embedded network is better than an arms-length network, at least for small firms. Third, the estimated interest rate does not fall below about 9.1 percent, yet the average prime rate over this period is 8.5 percent. This suggests that banks and clients share the benefits created by social attachments and social networks, yet on average this does not result in loan costs below prime-the bank's cost of capital. Rather, the results suggest that embeddedness prompts the bank and the firm to share the potential profits that could be made from the loan. A reasonable conjecture is that the social capital created by embeddedness in modern capitalist markets is both closely aligned with performance and less particularistic than typically assumed in classical financial theory.

\section{DISCUSSION}

Bankers have an adage, "a relationship is worth a basis point." This saying reflects their belief that value is measured the oldfashioned and unambiguous way-at the cash register-yet belies the real value they credit to relationships. Using an embedded- 
ness approach, I have found that commercial transactions between firms and banks that are embedded in relationships increase firms' access to capital and lower their borrowing costs net of other determinants of lending. Ethnographic and statistical evidence showed that the more commercial transactions between a firm and the bank it borrows from are embedded in social attachments, the more expectations of trust and reciprocity shape transacting, thereby promoting governance benefits and transfers of private resources that are inaccessible through market ties. The governance benefits of embedded ties make investments in unique solutions to lending problems more predictable to banks and firms, while the high level of private resource transfer provides the substantive material for creating distinctive solutions to a firm's financing needs. These findings are important because most studies of financial market behavior focus on access to public information and the use of formal governance mechanisms such as written contracts. Embeddedness is therefore a conduit to resources and governance arrangements that are difficult to emulate through other exchange mechanisms.

These benefits of embeddedness are also enhanced when the firm's network of ties to all its banks - those banks from which it borrows and those at which it conducts other banking business-consists of a complementary mix of embedded ties and arm's-length ties. Firms that have networks composed of a complementary mix of ties optimize the benefits of embeddedness because the characteristics of different types of ties offset each other's weaknesses while preserving their strengths. In networks high in complementarity, arm's-length ties effectively search for and broker differences in loan structures among banks, while embedded ties facilitate the partnering that is needed to successfully synthesize diverse market information and unique private resources into innovative, low-cost loan structures. In contrast, networks of only arm'slength ties can effectively broker market differences but lack arrangements that facilitate partnering, while networks of only embedded ties promote partnering yet have limited facilities for brokering resources between disconnected actors. I refer to this portfolio-like property of a network as network complementarity and view it as one way network structure optimizes an actor's brokering and partnering benefits vis-à-vis other actors.

Apart from the substantive ramifications of the findings, implications for the sociology of markets and organizations are also evident. In economic sociology, there are two general theories for understanding how social relations and networks create economic and social benefits. The weak-tie approach argues that a large, nonredundant network of arm's-length ties is most advantageous; the strong-tie approach argues that a closed, tightly knit network of embedded ties is most advantageous (Sandefur and Laumann 1998). How can these opposing approaches to tie quality (weak versus strong) and network structure ("holely" versus dense) be reconciled? My analysis of arm's-length ties supports the weak-tie thesis, demonstrating that weak ties are superior at "shopping" the market for publicly available information. Similarly, my analysis of embedded ties supports the strong-tie approach by showing that embedded ties are superior at "plugging" actors into the unique collective resources of dense network clusters. Thus, I suggest that embedded ties and arm's-length ties are complementary rather than cannibalistic when they are combined within the same network, because one type of tie helps overcome the limitations of the other type while enlarging information and governance benefits. While I have addressed these portfolio-like properties of network complementarity, the concept should be further developed and fully confirmed. Future research should be directed at accumulating additional evidence along the lines of this study on network complementarity and build on current work that includes studies of research productivity, learning, industrial change, and direct sales marketing (Etzkowitz, Kemelgor, and Uzzi forthcoming; Gabbay 1997; Talmud and Mesch 1997; Uzzi 1996).

The results also suggest that the theoretical distinction between instrumental versus expressive interests may be moot because embeddedness changes actors' motives rather than treats them as immutable. While RMs may build networks to gain access to private information, enacting a relationship 
also attenuates the narrow aims that may have motivated it originally because such ties tend to create expectations that normally accompany noneconomic attachments. As my data show, even in a business culture that uses the yardstick of money to gauge value, bankers and clients develop expressive bonds that affect their economic decisions. Consequently, there is no tradeoff between selfish interests and an exchange partner's interests because valuing an exchange partner's interest is appropriate for roles that are linked through embedded ties.

A class of theoretical implications concern the similarities and differences between the embeddedness approach and other approaches to transacting across organizational boundaries, particularly transaction cost economics, which also conceptualizes exchange in terms of information access and governance (Granovetter 1985; Uzzi 1996; 1997). In this paper, I have presented three factors that distinguish the ways in which information and governance problems are treated in the embeddedness and transaction cost economic approaches. Two differences concern the mechanisms by which information and governance problems are resolved (i.e., private information transfer and networks) and one difference concerns the motivations of actors (i.e., an embedded logic of exchange).

First, the embeddedness and transaction cost approaches differ in their emphases on the degree to which private information or asset specificity-the main explanatory variable of the transaction cost approach (also see Blau 1964:160 for an early treatment of asset-specificity's effect on exchange)_affect the value of relationships. While the concepts of private information and asset specificity are not necessarily in conflict with one another, private information and asset specificity are not synonymous. I have shown how private information is unlike asset-specific information in that private information need not be relationship-specific or decrease in value if redeployed in another transaction. Rather, it provides value through relationships and therefore does not necessarily lose value when redeployed in a new relationship or when used in several exchange relationships simultaneously. In this sense, private information shares with relationship specific investments the quality of value creation, but it has fewer restrictions on how widely it can be used.

Second, non-contractual social relationships and network structure also play a key role in embeddedness by regulating an actor's ability to broker and partner in exchanges-features of social structure that are given short shrift in the transaction cost economics focus on dyads.

Third, transaction cost economics holds that trust muddies the waters of individual calculativeness because "the only reliable human motive is avariciousness" (Williamson 1996:50). As such, the transaction cost model focuses on the use of formal governance mechanisms such as contracts, franchise agreements, or hostage-taking. In contrast, I have presented numerous examples and statistical findings that showed how social trust can offer distinctive governance benefits that translate into lower costs of capital and improved access to capital. Another important consequence of this distinction is that the governance arrangements of social embeddedness appear to come before, rather than follow from, the attributes of transactions. In this way, embeddedness inverts the logic of transaction costs by showing how self-enforcing governance arrangements pave the way for the transfer of private information and integrative bargaining rather than follow the attributes of transactions as purported in transaction cost economics.

While the triangulation of methods and independent data sources provides more robust inferences than does a single source of data, the cross-sectional properties of these materials suggests that the framework's confirmation requires longitudinal study of the origin, change, and scope of embeddedness in markets (Uzzi 1999). A specific provisional finding of this study is that women-managed and minority-managed firms are less likely than other firms to access credit. One reason for these discrepancies may be that the "scripts" that white male RMs use to forge ties with white male entrepreneurs are "coded" differently by minorities and women (e.g., an evening of dinner and the theatre becomes comparable to a "date") because relationship-building involves contextually defined activities. These differences may therefore unintentionally hamper the formation of em- 
bedded ties between groups that use alternative scripts. Thus, one tentative conclusion is that prejudices against an out-group may explain only part of the discrepancies in lending because collaboration among in-group members improves access for in-group members, even if out-group bias does not exist. Thus, if these provisos are correct they suggest that in-group effects may be as important as out-group effects in explaining market stratification. They also suggest that the systems lenders use to select and train RMs in relational practices can improve minorities' access to credit, as well as lenders' ability to attract the business of undervalued firms.

In summary, my key substantive conclusion is that social structure stratifies market outcomes by influencing both who gets credit and what that credit costs. My broad finding is that the ability to meet financial selection criteria is a product of a firm's characteristics as well as the socially arranged opportunity structures within which it is embedded. Firms with embedded relations and high network complementarity are more likely to be deemed credit eligible and to receive lower cost financing. While it has recently been recognized that particular networks can benefit firms in competitive environments, less attention has been paid to a second, commensurately important outcome of networks: that social and network relations also can encourage a firm to put forth extra effort, increasing its future performance beyond what it would have been had it been embedded in a more limiting set of relations. In this sense, embeddedness can promote both individual and social welfare in markets in the same way that advantaged social positions, independent of personal attributes, help actors get ahead and also motivate them to achieve. Conversely, disadvantaged positions stall mobility and reduce aspiration and motivation. Thus, market-making - or the creation of exchanges for mutual benefit-depends on social relations and networks, which are themselves likely to generate premium benefits for firms and economies when they provide a bridge for integrating the public resources of markets with the private resources of relationships.

Brian Uzzi is Associate Professor of Organization Behavior at the Kellogg Graduate School of Management and Associate Professor of Sociology at Northwestern University. He is also director of the Ph.D. program in Sociology and Organizations. In the 1999-2000 academic year, he will be a Fellow at the Institute for Policy Research at Northwestern and then a Visiting Professor at INSEAD, Fountainbleu France. His research interests include the economic sociology of organizations and markets with a current focus on the role of embeddedness in financial market making and organizational status processes. Two forthcoming projects are, Athena Unbound: Social Capital and the Advancement of Women in Science (with Henry Etzkowitz and Carol Kemelgor, Cambridge University Press), and Embedded Organizations: Sociological Conceptions on Organizational Evolution in Three Transitioning Economies (with Rueyling Tzeng, Stanford University Press).

\section{Appendix A. Fieldwork Methodology}

I obtained interviewees' names from each bank's CEO. The CEO's name was acquired through the Banking Resource Center, a research institute on banking located within the Kellogg Graduate School of Management. Banks sampled ranged in size from small community banks (assets $<\$ 100,000,000$ ) to high-end midmarket banks (assets $<\$ 225$ billion).

At each bank, I interviewed "relationship managers," a widely used title that displaced the former title of "lending officer" in the early 1980s. The title "Relationship Manager" (RM) is sociologically interesting in that it connotes the social nature and identity of this role in banks and the manner in which it is enacted with corporate clients. RMs normally attain the rank of vice president, a status that reflects seniority, success, and decision-making power. Of the 24 interviewees, 19 were RMs, three were CEOs actively involved in lending, and two were bad-debt collectors. Bad-debt collectors are presumably more skeptical of social ties than RMs given that their typical interactions are with persons and firms that default and defraud on loan agreements. Total interview time amounted to 26 hours, and the average number of years of experience of interviewees was about 10 years. The average number of firms that each interviewee managed ranged from 9 to 50. The gender and race demographics of the RM sample approximate the population demographics of the banking industry: five were women and one was an African American male.

I used Miles and Huberman's (1994) data collection and analysis methods. I recorded all interviews on tape and then transcribed them to create a behavioral record for each interviewee. In some cases, 
long narrative passages were broken into stanzas, which consisted of an uninterrupted series of sentences on a single topic (e.g., transactions, trust, market-making). In these cases and when narratives were reported in their entirety, the lack of fluency that is typical of spoken English was edited to increase comprehension. Questions were open-ended and moderately directive. Questions focused on the nature of the credit decision-especially access to capital (who qualifies) and the cost of capital. Follow-up questions focused on the nature, function, and dynamics of bank-client ties. Thus, there was an active attempt to use the interviews to discover interesting and surprising relationships, rather than to use them as a proxy for survey data. For example, some typical questions were: "How does the bank assess the creditworthiness of a corporate borrower?" "What types of things do you discuss with a client in order to assess their creditworthiness?" "What do you typically do when you meet clients?" "What is the basis of a good relationship with a client?" "How do relationships between you and the client develop?" To probe sensitive issues and avoid directiveness, responses were postscripted with phrases such as: "Can you tell me more about that? I am interested in those kinds of details," "Is there anything else?" "Would you consider this typical or atypical?"

Data analysis was a two-step procedure. First, I formed an understanding of the patterns in the data. This task centered on a content analysis and frequency count of the interviewees' data in which their responses were compiled into different factors that decomposed the range of responses (i.e., the variance) into its major components. Second, I worked back and forth between theory and the emerging framework. In this step, evidence was added, dropped, or revised as my working formulation took shape. My purpose was to explain how social structure influences economic behavior, which in this context considers how relationships and network ties condition a firm's access to capital and the cost of capital. Like psychometric and econometric models, this formulation aims to accurately illustrate the sources of variation in the data rather than explain all the variance.

\section{REFERENCES}

Abolafia, Mitchell Y. 1997. Making Markets: Opportunism and Restraint on Wall Street. Boston, MA: Harvard University Press.

Arrow, Kenneth J. 1998. "What Has Economics to Say about Racial Discrimination." Journal of Economic Perspectives 12(2):91-100.

Baker, Wayne E. 1990. "Market Networks and Corporate Behavior." American Journal of Sociology 6:589-625.

- 1994. Networking Smart: How to Build Relationships for Personal and Organizational Success. New York: McGraw-Hill.

Baker, Wayne E., Robert R. Faulkner, and Gene A. Fisher. 1998. "Hazards of the Market: The Continuity and Dissolution of Interorganizational Market Relationships." American Sociological Review 63:147-77.

Berger, Allen N., Anil K. Kashyap, and Joseph M. Scalise. 1995. "The Transformation of the U.S. Banking Industry: What a Long Strange Trip It's Been." Brookings Papers on Economic Activity 1:55-218.

Blau, Peter M. 1964. Exchange and Power in Social Life. New York: Wiley.

Blau, Peter M. and Joseph E. Schwartz. 1984. Crosscutting Social Circles. New York: Academic.

Bollen, Kenneth A. and Pamela Paxton. 1998. "Detection and Determinants of Bias in Subjective Measures." American Sociological Review 63:465-78.

Borgatti, Stephan P. 1997. "Structural Holes: Unpacking Burt's Redundancy Measures." Connections 20:35-8.

Burt, Ronald S. 1992. Structural Holes: The So- cial Structure of Competition. Boston, MA: Harvard University Press.

Carruthers, Bruce G. 1996. City of Capital: Politics and Markets in the English Financial Revolution. Princeton, NJ: Princeton University Press.

Cole, Rebel A. and John D. Wolken. 1995. "Financial Services Used by Small Businesses: Evidence from the 1993 National Survey of Small Business Finances." Federal Reserve Bulletin (July):629-67.

Coleman, James S. 1988. "Social Capital in the Creation of Human Capital." American Journal of Sociology 94(supp.):S95-S120.

Davis, Gerald F. 1991. "Agents without Principles: The Spread of the Poison Pill through the Intercorporate Network." Administrative Science Quarterly 36:583-613.

Davis, Gerald F. and Mark S. Mizruchi. 1999. "The Money Center Cannot Hold: Commercial Banks in the U.S. System of Corporate Governance." Administrative Science Quarterly 44:215-39.

DiMaggio, Paul and Hugh Louch. 1998. "Socially Embedded Consumer Transactions: For What Kinds of Purchases Do People Most Often Use Networks." American Sociological Review 63:619-37.

Eccles, Robert G. and Dwight B. Crane. 1988. Doing Deals: Investment Banks at Work. Boston, MA: Harvard Business School Press.

Ettin, Edward C. 1994. "The Evolution of the North American Banking System." Prepared for the Experts' Meeting on Structural Changes in Financial Markets: Trends and Practices, 
Organization for Economic Cooperation and Development, Paris, France.

Etzkowitz, Henry, Carol Kemelgor, and Brian Uzzi. Forthcoming. Athena Unbound: Social Capital and the Advancement of Women in Science. London, Enngland: Cambridge University Press.

Fama, Eugene. 1985. "What's Different about Banks?" Journal of Monetary Economics 15: 29-36.

FDIC. 1998. 1998 Bank and Thrift Branch Office Data Book: Office Deposits and Addresses of FDIC Insured Institutions-Summary of Deposits Central Region. Federal Deposit Insurance Corportation: Washington, DC.

Fligstein, Neil. 1996. "Markets as Politics: A Political-Cultural Approach to Market Institutions." American Sociological Review 61:65673.

Fukuyama, Francis. 1995. Trust, Social Virtues and the Creation of Prosperity. New York: Free Press.

Gabbay, Shaul. 1997. Social Capital in the Creation of Financial Capital: The Case of Network Marketing. Champaign, IL: Stipes.

Gorton, Gary and Richard Rosen. 1995. "Corporate Control, Portfolio Choice, and the Decline of Banking." Journal of Finance 50:1377-420.

Granovetter, Mark. 1973. "The Strength of Weak Ties." American Journal of Sociology 78: 1360-80.

- 1985. "Economic Action and Social Structure: The Problem of Embeddedness." American Journal of Sociology 91:481-510.

Gulati, Ranjay. 1994. "Does Familiarity Breed Trust? The Implications of Repeated Ties for Contractual Choice in Alliances." Academy of Management Journal 38(4):85-112.

Haunschild, Pamela R. 1994. "How Much is That Company Worth? Interorganizational Relationships, Uncertainty, and Acquisition Premiums." Administrative Science Quarterly 39: 391-411.

Hawley, Clifford B. and Edwin T. Fujii. 1991. "Discrimination in Consumer Credit Markets." Eastern Economic Journal 17(1):21-30.

Heckman, James. 1976. "The Common Structure of Statistical Models of Truncation, Sample Selection, and Limited Dependent Variables and a Simple Estimator for Such Models." The Annals of Economic and Social Measurement 5:475-92.

Hirschman, Albert O. 1977. The Passions and the Interests: Political Arguments for Capitalism before its Triumph. Princeton, NJ: Princeton University Press.

- 1982. "Rival Interpretations of Market Society: Civilizing, Destructive, or Feeble?" Journal of Economic Literature 20:1463-84.

Iacobucci, Dawn and Amy Ostrom. 1996. "Com- mercial and Interpersonal Relationships: Using the Structure of Interpersonal Relationships to Understand Individual-to-Individual, Individual-to-Firm, and Firm-to-Firm Relationships in Commerce." International Journal of Research in Marketing 13:53-72.

King, Gary, Robert O. Keohane, and Sidney Verba. 1994. Designing Social Inquiry: Scientific Inference in Qualitative Research. Princeton, NJ: Princeton University Press.

Kollock, Peter. 1994. "The Emergence of Exchange Structures: An Experimental Study of Uncertainty, Commitment, and Trust." American Journal of Sociology 100:313-45.

Kunda, Ziva. 1990. "The Case for Motivated Reasoning." Psychological Bulletin 108:480-98.

Larson, Andrea. 1992. "Network Dyads in Entrepreneurial Settings: A Study of the Governance of Exchange Processes." Administrative Science Quarterly 37:76-104.

Lazerson, Mark. 1995. "A New Phoenix: Modern Putting-Out in the Modena Knitwear Industry." Administrative Science Quarterly 40:34-59.

Levinthal, Daniel A. and Mark Fichman. 1988. "Dynamics of Interorganizational Attachments: Auditor-Client Relationships." Administrative Science Quarterly 33:345-69.

Lie, John. 1997. "Sociology of Markets." Annual Review of Sociology 23:341-60.

Lin, Nan, Walter Ensel, and Jan Vaughn. 1981. "Social Resources and Strength of Ties: Structural Factors in Occupational Status Attainment." American Sociological Review 46:393405.

Lummer, Scott and John McConnell. 1989. "Further Evidence on the Bank Lending Process and the Capital Market Response to Bank Loan Agreements." Journal of Financial Economics 25:99-112.

Macneil, Ian. Forthcoming. "Relational Contract Theory: Challenges." Northwestern University Law Review.

March, James G. 1994. A Primer on Decision Making: How Decisions Happen. New York: Free Press.

Marsden, Peter V. 1981. "Introducing Influence Processes into a System of Collective Decisions." American Journal of Sociology 86: 1203-35.

Marsden, Peter V. and Karen E. Campbell. 1984. "Measuring Tie Strength." Social Forces 63: 482-501.

McPherson, Miller J., Pamela A. Popielarz, and Sonja Drobnic. 1992. "Social Networks and Organizational Dynamics." American Sociological Review 57:153-70.

Miles, Matthew B. and Michael Huberman. 1994. Qualitative Data Analysis. Newbury Park, CA: Sage.

Mintz, Beth and Michael Schwartz. 1985. The 
Power Structure of American Business. Chicago, IL: University of Chicago Press.

Mizruchi, Mark S. and Linda B. Stearns. 1994a. "A Longitudinal Study of Borrowing by Large American Corporations." Administrative Science Quarterly 39:118-40.

. 1994b. "Money, Banking, and Financial Markets." Pp. 313-41 in Handbook of Economic Sociology, edited by N. J. Smelser and R. Swedberg. Princeton, NJ: Princeton University Press.

Montgomery, James D. 1998. "Toward a RoleTheoretic Conception of Embeddedness." American Journal of Sociology 104:92-125.

Munnell, Alicia H., Lynn E. Browne, James McEneaney, and Geoffrey M. B. Tootell. 1992. "Mortgage Lending in Boston: Interpreting HMDA Data." Working Paper 92-7, Federal Reserve Bank of Boston, Boston, MA.

Padgett, John F. and Christopher K. Ansell. 1993. "Robust Action and the Rise of the Medici, 1400-1434." American Journal of Sociology 98:1259-319.

Petersen, Mitchell A. and Raghuram G. Rajan. 1994. "The Benefits of Lending Relationships: Evidence from Small Business Data." The Journal of Finance 49(1):3-37.

. 1995. "The Effect of Credit Market Competition on Lending Relationships." Quarterly Journal of Economics 110:407-43.

Podolny, Joel M. 1993. "A Status-Based Model of Market Competition." American Journal of Sociology 98:829-72.

Portes, Alejandro and Julia Sensenbrenner. 1993. "Embeddedness and Immigration: Notes on the Social Determinants of Economic Action." American Journal of Sociology 98:1320-50.

Powell, Walter W. 1990. "Neither Market nor Hierarchy: Network Forms of Organization." Pp. 295-336 in Research in Organizational Behavior, edited by B. Staw and L. L. Cummings. Greenwich, CT: JAI Press.

Powell, Walter W., Kenneth W. Koput, and Laurel Smith-Doerr. 1996. "Interorganizational Collaboration and the Locus of Innovation: Networks of Learning in Biotechnology." Administrative Science Quarterly 41:116-45.

Romo, Frank P. and Michael Schwartz. 1995. "Structural Embeddedness of Business Decisions: A Sociological Assessment of the Migra- tion Behavior of Plants in New York State Between 1960 and 1985." American Sociological Review 60:874-907.

Sandefur, Rebecca L. and Edward O. Laumann. 1998. "A Paradigm for Social Capital." Rationality and Society 10:481-501.

Seabright, Mark A., Daniel A. Levinthal, and Mark Fichman. 1992. "Role of Individual Attachments in the Dissolution of Interorganizational Relationships." The Academy of Management Journal 35(1):122-60.

Smelser, Neil J. and Richard Swedberg. 1994. "The Sociological Perspective on the Economy." Pp. 3-26 in The Handbook of Economic Sociology, edited by N. J. Smelser and R. Swedberg. Princeton, NJ: Princeton University Press.

Spulber, Daniel F. 1998. The Market Makers. New York: McGraw-Hill.

Talmud, Ilan and Gustavo Mesch. 1997. "Market Embeddedness and Corporate Instability: The Econology of Inter-Industrial Networks." Social Science Research 26:419-41.

Uzzi, Brian. 1996. "The Sources and Consequences of Embeddedness for the Economic Performance of Organizations." American Sociological Review 61:674-98.

. 1997. "Social Structure and Competition in Interfirm Networks: The Paradox of Embeddedness." Administrative Science Quarterly 42:35-67.

1999. "Governance Benefits through Embedded Ties and Network Complementarity: The Case of Banks Making Corporate Loans." Working Paper 99-15. Institute for Policy Analysis, Northwestern University, Evanston, IL.

Uzzi, Brian and James J. Gillespie. 1999. "Interfirm Ties and the Organization of the Firm's Capital Structure in the Middle Financial Market." Pp. 107-26 in Research in the Sociology of Organizations, edited by D. Knoke and S. Andrews. Stanford, CT: JAI Press.

Weber, Max. [1922] 1946. "Class Status and Party." Pp. 180-95 in From Max Weber: Essays in Sociology, edited by H. H. Gerth and C. W. Mills. Reprint, New York: Oxford University Press.

Williamson, Oliver. 1996. "Economic Organization: The Case for Candor." The Academy of Management Review 21(1):48-57. 